\title{
ANALISIS FAKTOR-FAKTOR YANG MEMPENGARUHI STRUKTUR MODAL PERUSAHAAN AGRIBISNIS DI BURSA EFEK INDONESIA TAHUN 2007-2012
}

\section{(ANALYSIS OF FACTORS AFFECTING CAPITAL STRUCTURE OF THE AGRIBUSINESS COMPANIES IN INDONESIA STOCK EXCHANGE YEAR 2007-2012)}

\author{
Wahyu Handono'), Effed Darta'2), dan M. Zulkarnain Yuliarso ${ }^{3)}$ \\ 1) Magister Agribisnis, Fakultas Pertanian, Universitas Bengkulu \\ 2) Jurusan Manajemen, Fakultas Ekonomi Universitas Bengkulu \\ 3) Jurusan Sosial Ekonomi Pertanian, fakultas Pertanian, Unversitas Bengkulu
}

\begin{abstract}
The purpose of this study is to determine the influence of factors of sales growth, tangibility of assets, profitability, liquidity and firm size of capital structure on agribusiness corporates listed on the Indonesia Stock Exchange during 2007-2012. The population used in this study is a company listed on the Indonesia Stock Exchange (BEI) in the period from 2007 to 2012 and is engaged in agribusiness (food crops, plantations, livestock, fisheries, and forestry). The selection of the sample used purposive sampling method. Based on the criteria, 11 companies samples are obtained in the period 2007-2012. The analysis used multiple regression analysis. This research assumed some variables that significantly influence the capital structure (DTA) are the tangibility of assets (FTA), liquidity (CR) and size of company (Size). While the growth in sales (GS) and profitability (NPM) variables had no significant effect on capital structure (DTA). The research result indicates that simultaneous growth in sales (GS), tangibilty of assets (FTA), profitability (NPM), liquidity (CR) and firm size (Size) significantly influence the capital structure (DTA) of the agribusiness company.
\end{abstract}

Keywords: agribusiness companies, capital structure

\section{PENDAHULUAN}

Perusahaan agribisnis saat ini merupakan perusahaan yang cukup berkembang dan diminati oleh para investor terutama di pasar modal, hal ini ditandai dengan semakin banyaknya jumlah perusahaan agribisnis yang telah listing di Bursa Efek Indonesia (BEI). Kemampuan perusahaan agribisnis untuk survive, tumbuh dan menguat pada kondisi krisis ekonomi lokal maupun 
global, merupakan motivasi bagi investor untuk melakukan investasinya pada perusahaan-perusahaan tersebut.

Perusahaan agribisnis merupakan perusahaan yang berbasis pada pengembangan sektor pertanian dalam arti luas dari hilir sampai hulu dengan berbagai subsistem yang mendasarinya. Sektor agribisnis mempunyai pengaruh yang sangat besar dan memiliki nilai strategis terhadap pembangunan Indonesia, ini disebabkan karena potensi sumber daya alam dan sumber daya manusia Indonesia sangat mendukung usaha bidang pertanian. Selain itu sektor agribisnis merupakan penyumbang pendapatan nasional terbesar sebagai salah satu sumber devisa negara, karena sebagian besar devisa negara dari sektor non migas berasal dari agribisnis. Berdasarkan data statistik dari Bursa Efek Indonesia (BEI), bahwa pada tahun 2007-2012 tercatat sebanyak 18 perusahaan yang termasuk dalam kelompok sektor primer pertanian (agriculture) dan sektor industri hewan ternak (animal). Menurut JASICA Index, klasifikasi subsektor perusahaan agribisnis terbagi atas kode indeks : (11) Crops, (12) Plantations, (13) Animal Husbandry, (36) Animal Feed dan (91) Wholesale.

Pertumbuhan dan penguatan usaha sektor agribisnis tentunya tidak lepas dari beberapa keputusan yang mendukung perusahaan tersebut. Salah satu keputusan penting dalam kaitannya dengan kelangsungan operasi perusahaan adalah keputusan pendanaan atau keputusan struktur modal, yaitu keputusan keuangan yang berkaitan dengan komposisi utang, saham preferen dan saham biasa (Wijayati dan Janie, 2012).

Struktur modal perusahaan merupakan salah satu faktor fundamental dalam operasi perusahaan. Struktur modal suatu perusahaan ditentukan oleh kebijakan pembelanjaan (financing policy) dari manajer keuangan yang senantiasa dihadapkan pada pertimbangan baik yang bersifat kualitatif maupun kuantitatif (Kartika, 2009). Salah satu unsur yang perlu diperhatikan dalam mengelola fungsi keuangan adalah seberapa besar perusahaan mampu memenuhi kebutuhan dana yang akan digunakan untuk beroperasi dan mengembangkan usahanya. Pemenuhan dana ini bisa bersumber dari dana sendiri, modal saham maupun dengan utang, baik utang jangka pendek maupun utang jangka panjang. Ketika manajer menggunakan utang (debt), maka biaya yang timbul sebesar biaya bunga yang dibebankan oleh kreditur, sedangkan jika manajer menggunakan dana sendiri (equity) maka akan timbul opportunity cost dari modal sendiri yang digunakan (Wijayati dan Janie, 2012). Sehingga semakin besar struktur modal perusahaan tersebut berarti semakin besar resiko yang ditanggung sebuah perusahaan karena semakin banyak utang yang ditanggung untuk melakukan operasinya.

Keputusan pendanaan keuangan perusahaan akan sangat menentukan kemampuan perusahaan dalam melakukan aktivitas operasinya dan juga akan berpengaruh terhadap resiko perusahaan itu sendiri. Keputusan pendanaan oleh manajemen akan berpengaruh pada penilaian perusahaan yang terefleksi 
di harga saham (Harmono, 2009). Jika perusahaan meningkatkan leverage maka perusahaan ini dengan sendirinya akan meningkatkan resiko keuangan perusahaan, dan sebaliknya perusahaan harus memperhatikan masalah pajak, karena sebagian ahli berpendapat bahwa penggunaan modal yang berlebihan akan menurunkan tingkat profitabilitas (Kartika, 2009). Untuk itu sebagian manajer tidak sepenuhnya mendanai perusahaannya dengan modal tetapi juga disertai penggunaan dana melalui utang baik itu utang jangka pendek maupun utang jangka panjang karena terkait dengan sifat penggunaan dari utang tersebut yaitu bersifat mengurangi pajak.

Dengan demikian tujuan penelitian ini dimaksudkan untuk menganalisis apakah terdapat pengaruh pertumbuhan penjualan (GS), struktur aktiva (FTA), profitabilitas (NPM), likuiditas (CR) dan ukuran perusahaan (Size) terhadap struktur modal (DTA) pada perusahaan agribisnis yang terdaftar di Bursa Efek Indonesia baik secara parsial maupun simultan dengan periode pengamatan tahun tertentu (2007-2012).

\section{METODE PENELITIAN}

Populasi yang digunakan dalam penelitian ini adalah perusahaan yang listing pada Bursa Efek Indonesia (BEI) periode 2007-2012 dan bergerak dalam bidang agribisnis (tanaman pangan, perkebunan, peternakan, perikanan dan kehutanan). Jumlah populasi dalam penelitian ini adalah 18 perusahaan agribisnis (ICMD, 2007-2012).

Pemilihan sampel dilakukan berdasarkan metode Purposive Sampling berdasarkan kriteria tertentu. Kriteria perusahaan yang dijadikan sampel dalam penelitian ini adalah: Perusahaan agribisnis yang go-public atau listing di BEI periode tahun 2007-2012, tersedianya laporan keuangan tahunan selama tahun 2007-2012 dan perusahaan agribisnis yang melakukan penghapusan pencatatan (delisting) pada periode tahun 2007-2012 di BEI tidak dimasukkan ke dalam sampel. Berdasarkan kriteria tersebut, didapatkan 11 sampel perusahaan agribisnis yang memenuhi kriteria dan layak diteliti diamati selama periode 6 tahun yaitu tahun 2007 sampai dengan tahun 2012, dengan demikian terdapat 66 kali pengamatan (66 jumlah sampel).

Data yang digunakan adalah data sekunder, yaitu data yang telah dikumpulkan oleh pihak lain dalam hal ini adalah data yang dipublish oleh perusahaan tersebut ataupun diperoleh dari Indonesian Capital Market Directory (ICMD). Berdasarkan sumber data tersebut maka data yang dicari meliputi data: Total Asset (TA), Current Asset (CA), Fixed Asset (FA), Total Liabilities (TL), Current Liabilities (CL), Sales, Profit After Tax dan Net Profit Margin (NPM). Metode pengambilan data yang digunakan merupakan data pooling (Kuncoro, 2003), yaitu kombinasi metode pengambilan data antara runtut waktu (time series) dan silang tempat (cross section). 
Penelitian ini akan menggunakan metode Analisis Regresi Berganda, model yang dimaksud adalah sebagai berikut:

$$
\mathrm{DTA}=\mathrm{a}+\mathrm{b}_{1} \mathrm{GS}+\mathrm{b}_{2} \mathrm{FTA}+\mathrm{b}_{3} \mathrm{NPM}+\mathrm{b}_{4} \mathrm{CR}+\mathrm{b}_{5} \mathrm{SIZE}+\mathrm{e}
$$

dimana DTA adalah struktur modal, GS adalah pertumbuhan penjualan, FTAadalah struktur aktiva atau tangible assets, NPM adalah profitabilitas, CRadalah likuiditas, SIZE adalah ukuran perusahaan, a adalah intercept atau konstanta, $b_{1}, b_{2}, b_{3}, b_{4}, b_{5}$ adalah koefisien regresi variabel independen, dan e adalah error

Identifikasi variabel dan definisi operasional secara terperinci disajikan dalam tabel berikut:

Tabel 1. Definisi Operasional Variabel

\begin{tabular}{|c|c|c|c|c|c|}
\hline No & Variabel & Definisi & Simbol & Skala & Penghitungan \\
\hline 1. & $\begin{array}{l}\text { Struktur } \\
\text { Modal }\end{array}$ & $\begin{array}{l}\text { Rasio antara total utang } \\
\text { dengan total assets. }\end{array}$ & DTA & $\begin{array}{l}\text { Rasio } \\
\text { dirubah } \\
\text { ke } \\
\text { persentase }\end{array}$ & $\begin{array}{l}\text { Total liabilities } \\
\mathrm{x} 100 \% \\
\text { Total assets }\end{array}$ \\
\hline 2. & $\begin{array}{l}\text { Pertumbuhan } \\
\text { Penjualan }\end{array}$ & $\begin{array}{llr}\text { Rasio } & \text { kenaikan } & \text { atau } \\
\text { penurunan } & \text { penjualan dari } \\
\text { periode } & \text { ke } & \text { periode } \\
\text { selanjutnya. } & & \end{array}$ & GS & $\begin{array}{l}\text { Rasio } \\
\text { dirubah } \\
\text { ke } \\
\text { persentase }\end{array}$ & $\begin{array}{l}\text { Penj. }(t)-\text { Penj. }(t-1) \\
\times 100 \% \\
\text { Penj. }(t-1)\end{array}$ \\
\hline 3. & $\begin{array}{l}\text { Tangible } \\
\text { Assets }\end{array}$ & $\begin{array}{l}\text { Rasio antara aktiva tetap } \\
\text { dengan total aktiva yang } \\
\text { dimiliki perusahaan }\end{array}$ & FTA & $\begin{array}{l}\text { Rasio } \\
\text { dirubah } \\
\text { ke } \\
\text { persentase }\end{array}$ & $\frac{\text { Fixed Asset }}{\text { Total Asset }} \times 100 \%$ \\
\hline 4. & Profitabilitas & $\begin{array}{l}\text { Rasio yang menghitung } \\
\text { sejauh mana kemampuan } \\
\text { perusahaan menghasilkan } \\
\text { laba bersih pada tingkat } \\
\text { penjualan tertentu antara } \\
\text { laba bersih terhadap } \\
\text { penjualan. }\end{array}$ & NPM & $\begin{array}{l}\text { Rasio } \\
\text { dirubah } \\
\text { ke } \\
\text { persentase }\end{array}$ & $\begin{array}{l}\frac{\text { Net Profit After Tax }}{\mathrm{x} 100 \%} \\
\text { Sales }\end{array}$ \\
\hline 5. & Likuiditas & $\begin{array}{l}\text { Rasio yang membandingkan } \\
\text { aktiva lancar yang dimiliki } \\
\text { perusahaan dengan utang } \\
\text { jangka pendek }\end{array}$ & CR & $\begin{array}{l}\text { Rasio } \\
\text { dirubah } \\
\text { ke } \\
\text { persentase }\end{array}$ & $\begin{array}{l}\frac{\text { Current Assets }}{100 \%} \\
\text { Current Liabilities }\end{array}$ \\
\hline 6. & Firm Size & $\begin{array}{l}\text { Ukuran perusahaan yang } \\
\text { diproyeksikan antara } \\
\text { LogNatural dari total assets }\end{array}$ & SIZE & $\begin{array}{l}\text { Ln dari } \\
\text { total assets }\end{array}$ & Ln Total Asset \\
\hline
\end{tabular}

Sumber: Konsep penelitian yang diolah dari berbagai buku 


\section{HASIL DAN PEMBAHASAN}

\section{Rasio Keuangan Perusahaan Agribisnis Periode 2007-2012}

Penghitungan rasio dilakukan dengan cara menggunakan rumus pada konsep dan pengukuran variabel terhadap data-data laporan keuangan perusahaan agribisnis yang diperoleh dari data ICMD periode 2007-2012. Hasil rasio yang diperoleh berdasarkan perhitungan laporan keuangan selanjutnya dirubah menjadi persentase (\%), kecuali untuk variabel ukuran perusahaan (Size). Alasan perubahan rasio menjadi bentuk persentase (\%) adalah untuk memudahkan interprestasi variabel-variabel tersebut. Sedangkan variabel ukuran perusahaan (Size) adalah merupakan proyeksi antara LogNatural dari total assets sehingga bukan merupakan rasio.

Berikut hasil variabel rasio keuangan perusahaan agribisnis yang diperoleh yaitu :

Tabel 2. Rasio Keuangan PT Astra Agro Lestari Tbk 2007-2012, (dalam \% kecuali size)

\begin{tabular}{cccccccc}
\hline No. & Tahun & DTA & GS & FTA & NPM & CR & Size \\
\hline 1 & 2007 & 21,49 & 58,62 & 32,80 & 33,11 & 160,30 & 15,49 \\
2 & 2008 & 18,15 & 36,91 & 30,70 & 32,24 & 194,42 & 15,69 \\
3 & 2009 & 15,12 & $-9,03$ & 32,29 & 22,37 & 182,58 & 15,84 \\
4 & 2010 & 15,18 & 19,12 & 30,56 & 22,80 & 193,17 & 15,99 \\
5 & 2011 & 17,43 & 21,81 & 33,56 & 23,19 & 130,97 & 16,14 \\
6 & 2012 & 24,59 & 7,35 & 39,60 & 21,79 & 68,46 & 16,33 \\
\hline
\end{tabular}

Sumber: ICMD, 2007-2012 (diolah)

Tabel 3. Rasio Keuangan PT BISI International Tbk 2007-2012, (dalam \% kecuali size)

\begin{tabular}{cccccccc}
\hline No. & Tahun & DTA & GS & FTA & NPM & CR & Size \\
\hline 1 & 2007 & 33,45 & 55,07 & 17,85 & 16,88 & 256,93 & 13,70 \\
2 & 2008 & 41,31 & 82,99 & 16,30 & 24,47 & 207,44 & 14,32 \\
3 & 2009 & 24,59 & $-51,95$ & 19,30 & 9,69 & 327,44 & 14,16 \\
4 & 2010 & 10,86 & 14,41 & 19,02 & 16,03 & 846,30 & 14,13 \\
5 & 2011 & 15,75 & 11,60 & 16,88 & 14,63 & 607,86 & 14,23 \\
6 & 2012 & 13,16 & $-13,26$ & 15,95 & 14,93 & 807,70 & 14,28 \\
\hline
\end{tabular}

Sumber: ICMD, 2007-2012 (diolah) 
Tabel 4. Rasio Keuangan PT Charoen Pokphand Indonesia Tbk 2007-2012, (dalam \% kecuali size)

\begin{tabular}{cccccccc}
\hline No. & Tahun & DTA & GS & FTA & NPM & CR & Size \\
\hline 1 & 2007 & 77,36 & 30,29 & 29,46 & 2,14 & 123,11 & 15,38 \\
2 & 2008 & 74,23 & 52,23 & 32,00 & 1,92 & 130,64 & 15,46 \\
3 & 2009 & 44,82 & 10,19 & 31,51 & 11,08 & 181,75 & 15,49 \\
4 & 2010 & 31,24 & 3,56 & 29,63 & 14,66 & 292,51 & 15,69 \\
5 & 2011 & 30,05 & 19,10 & 36,15 & 13,12 & 384,84 & 16,00 \\
6 & 2012 & 33,79 & 18,67 & 37,19 & 12,59 & 331,28 & 16,33 \\
\hline
\end{tabular}

Sumber: ICMD, 2007-2012 (diolah)

Tabel 5. Rasio Keuangan PT Central Proteinaprima Tbk 2007-2012, (dalam $\%$ kecuali size)

\begin{tabular}{cccccccc}
\hline No. & Tahun & DTA & GS & FTA & NPM & CR & Size \\
\hline 1 & 2007 & 80,24 & 25,00 & 43,08 & 5,85 & 283,66 & 15,87 \\
2 & 2008 & 64,22 & 33,43 & 45,34 & $-4,98$ & 208,62 & 16,05 \\
3 & 2009 & 62,99 & $-16,37$ & 46,03 & $-3,18$ & 190,04 & 15,98 \\
4 & 2010 & 69,36 & $-8,62$ & 43,34 & $-10,18$ & 72,63 & 15,95 \\
5 & 2011 & 92,27 & 20,59 & 38,34 & $-27,04$ & 56,16 & 15,77 \\
6 & 2012 & 98,46 & $-9,21$ & 35,25 & $-6,38$ & 57,78 & 15,78 \\
\hline
\end{tabular}

Sumber: ICMD, 2007-2012 (diolah)

Tabel 6. Rasio Keuangan PT Dharma Samudra Fishing Industries Tbk 20072012, (dalam \% kecuali size)

\begin{tabular}{cccccccc}
\hline No. & Tahun & DTA & GS & FTA & NPM & CR & Size \\
\hline 1 & 2007 & 40,69 & 31,08 & 25,85 & 0,84 & 166,76 & 12,66 \\
2 & 2008 & 52,72 & 2,57 & 34,91 & $-27,89$ & 124,15 & 12,41 \\
3 & 2009 & 88,12 & $-35,17$ & 52,48 & $-59,61$ & 51,72 & 11,84 \\
4 & 2010 & 85,26 & $-27,78$ & 46,10 & 4,19 & 416,92 & 11,89 \\
5 & 2011 & 77,47 & 42,63 & 41,25 & 4,13 & 332,00 & 11,99 \\
6 & 2012 & 61,98 & 73,45 & 53,13 & 16,14 & 370,86 & 12,31 \\
\hline
\end{tabular}

Sumber: ICMD, 2007-2012 (diolah)

Tabel 7. Rasio Keuangan PT Inti Agri Resources Tbk 2007-2012, (dalam \% kecuali size)

\begin{tabular}{cccccccc}
\hline No. & Tahun & DTA & GS & FTA & NPM & CR & Size \\
\hline 1 & 2007 & 1,70 & 103,06 & 36,11 & 25,81 & 844,20 & 12,93 \\
2 & 2008 & 0,40 & $-12,48$ & 40,99 & 21,88 & $3.961,17$ & 12,94 \\
3 & 2009 & 1,29 & $-62,03$ & 40,19 & $-33,67$ & 885,60 & 12,93 \\
4 & 2010 & 0,44 & 34,71 & 39,25 & $-10,94$ & $2.613,27$ & 12,91 \\
5 & 2011 & 0,39 & $-64,26$ & 41,09 & $-179,84$ & $1.672,69$ & 12,85 \\
6 & 2012 & 5,58 & 47,85 & 38,80 & $-79,83$ & 63,97 & 12,87 \\
\hline
\end{tabular}

Sumber: ICMD, 2007-2012 (diolah) 
Tabel 8. Rasio Keuangan PT JAPFA Comfeed Indonesia Tbk 2007-2012 (dalam \% kecuali size)

\begin{tabular}{cccccccc}
\hline No. & Tahun & DTA & GS & FTA & NPM & CR & Size \\
\hline 1 & 2007 & 76,53 & 23,46 & 34,54 & 2,29 & 244,69 & 15,21 \\
2 & 2008 & 77,47 & 45,81 & 29,51 & 2,19 & 173,34 & 15,50 \\
3 & 2009 & 60,96 & 24,44 & 29,73 & 5,68 & 220,61 & 15,62 \\
4 & 2010 & 50,04 & $-2,68$ & 31,92 & 6,87 & 262,95 & 15,76 \\
5 & 2011 & 54,21 & 12,02 & 35,49 & 3,95 & 159,11 & 15,93 \\
6 & 2012 & 56,54 & 14,07 & 37,11 & 5,56 & 182,45 & 16,21 \\
\hline
\end{tabular}

Sumber: ICMD, 2007-2012 (diolah)

Tabel 9. Rasio Keuangan PT London Sumatera Tbk 2007-2012, (dalam \% kecuali size)

\begin{tabular}{cccccccc}
\hline No. & Tahun & DTA & GS & FTA & NPM & CR & Size \\
\hline 1 & 2007 & 41,22 & 36,38 & 28,14 & 9,01 & 109,74 & 15,19 \\
2 & 2008 & 35,04 & 31,27 & 27,99 & 24,12 & 170,06 & 15,41 \\
3 & 2009 & 21,41 & $-16,81$ & 33,05 & 22,11 & 140,54 & 15,39 \\
4 & 2010 & 18,11 & 12,28 & 31,08 & 28,76 & 239,27 & 15,53 \\
5 & 2011 & 14,02 & 30,45 & 26,86 & 36,31 & 481,93 & 15,73 \\
6 & 2012 & 16,84 & $-10,13$ & 29,53 & 26,50 & 327,30 & 15,84 \\
\hline
\end{tabular}

Sumber: ICMD, 2007-2012 (diolah)

Tabel 10. Rasio Keuangan PT Mallindo Feedmill Tbk 2007-2012, (dalam \% kecuali size)

\begin{tabular}{cccccccc}
\hline No. & Tahun & DTA & GS & FTA & NPM & CR & Size \\
\hline 1 & 2007 & 70,99 & 33,03 & 42,15 & 2,37 & 84,37 & 13,39 \\
2 & 2008 & 94,82 & 45,52 & 30,79 & 0,24 & 116,64 & 13,66 \\
3 & 2009 & 86,60 & 8,03 & 32,98 & 4,07 & 132,19 & 13,69 \\
4 & 2010 & 73,52 & 8,99 & 33,28 & 8,83 & 142,30 & 13,78 \\
5 & 2011 & 68,23 & 29,36 & 42,28 & 7,78 & 139,88 & 14,10 \\
6 & 2012 & 62,12 & 27,14 & 47,49 & 9,03 & 104,86 & 14,40 \\
\hline
\end{tabular}

Sumber: ICMD, 2007-2012 (diolah)

Tabel 11. Rasio Keuangan PT Bakrie Sumatra Plantations Tbk 2007-2012 (dalam $\%$ kecuali size)

\begin{tabular}{cccccccc}
\hline No. & Tahun & DTA & GS & FTA & NPM & CR & Size \\
\hline 1 & 2007 & 44,64 & 65,08 & 17,19 & 10,60 & 317,30 & 15,28 \\
2 & 2008 & 47,43 & 50,40 & 15,83 & 5,92 & 148,84 & 15,36 \\
3 & 2009 & 47,34 & $-20,68$ & 13,55 & 10,87 & 101,02 & 15,44 \\
4 & 2010 & 53,80 & 29,21 & 38,30 & 26,81 & 53,50 & 16,73 \\
5 & 2011 & 51,57 & 21,36 & 37,54 & 20,45 & 39,77 & 16,74 \\
6 & 2012 & 58,31 & $-31,83$ & 35,24 & $-42,95$ & 126,24 & 16,76 \\
\hline
\end{tabular}

Sumber: ICMD, 2007-2012 (diolah) 
Tabel 12. Rasio Keuangan PT Wahana Phonix Mandiri Tbk 2007-2012, (dalam $\%$ kecuali size)

\begin{tabular}{cccccccc}
\hline No. & Tahun & DTA & GS & FTA & NPM & CR & Size \\
\hline 1 & 2007 & 58,59 & $-8,72$ & 18,77 & 0,08 & 146,57 & 12,20 \\
2 & 2008 & 60,22 & $-3,81$ & 17,01 & $-0,25$ & 139,15 & 12,24 \\
3 & 2009 & 60,30 & $-19,61$ & 15,91 & 0,09 & 140,96 & 12,24 \\
4 & 2010 & 66,72 & $-65,48$ & 15,00 & $-34,46$ & 124,35 & 12,23 \\
5 & 2011 & 101,99 & $-49,49$ & 91,61 & $-335,40$ & 48,92 & 11,29 \\
6 & 2012 & 97,55 & 503,10 & 72,04 & 3,18 & 106,87 & 11,49 \\
\hline
\end{tabular}

Sumber: ICMD, 2007-2012 (diolah)

\section{Hasil Estimasi Model dan Intepretasi Hasil}

Hasil estimasi model disajikan pada Tabel 13 berikut.

Tabel 13. Hasil Estimasi Struktur Modal Perusahaan Agribisnis

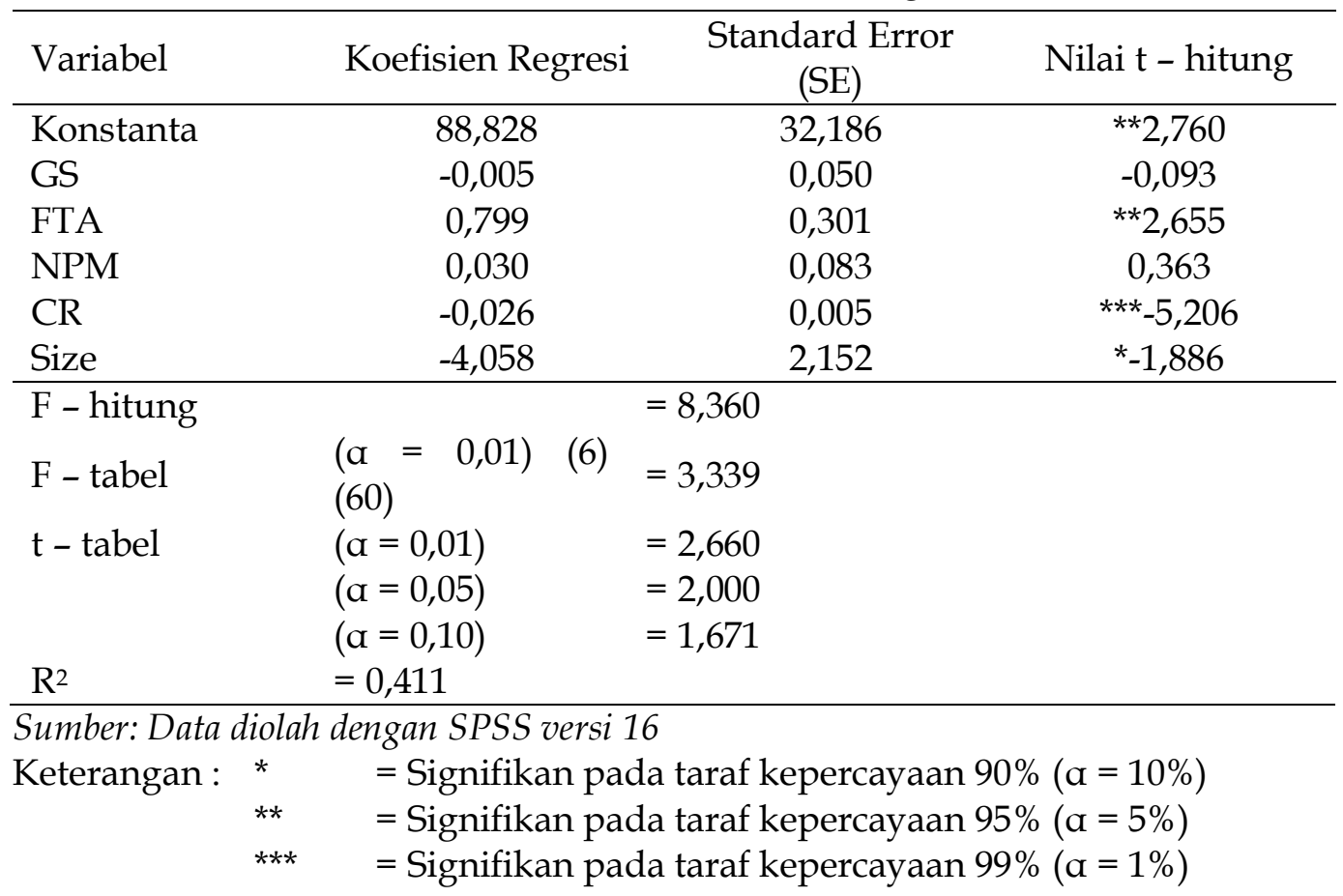

Berdasarkan penghitungan uji determinasi ( $\mathrm{R}$ square), diperoleh hasil 0,411 . Hal ini dapat diartikan bahwa variabel independen, yaitu: pertumbuhan penjualan (GS), struktur aktiva (FTA), profitabilitas (NPM), likuiditas (CR) dan ukuran perusahaan (Size) dapat menjelaskan variabel bebas struktur modal (DTA) sebesar $41,10 \%$, sedangkan sisanya dijelaskan oleh variabel lain yang tidak diamati dalam penelitian ini.

Wahyu Handono, Effed Data, dan M. Zulkarnain Yuliarso. Analisa... | 232 
Uji F dilakukan untuk menguji hubungan regresi antar variabel dependen dengan seperangkat variabel independen. Hipotesa untuk uji $\mathrm{F}$ adalah sebagai berikut: $\mathrm{H}_{6}$ : GS, FTA, NPM, CR dan Size secara simultan berpengaruh signifikan terhadap DTA. Dari penghitungan uji F-statistik, diperoleh nilai $\mathrm{F}_{\text {hitung }}$ adalah 8,360 sedangkan nilai $\mathrm{F}_{\text {tabel }}$ adalah 3,339 (pada $\mathrm{a}=$ $1 \%$ ), sehingga $\mathrm{F}_{\text {hitung }}>\mathrm{F}_{\text {tabel. }}$. Nilai $\mathrm{P}$-value dari $\mathrm{F}$, atau tingkat signifikansi diperoleh hasil sebesar $0,000<a=1 \%$. Sesuai dengan kriteria uji $F$ maka diperoleh 8,360 ( $\mathrm{F}$ hitung $)>3,339$ ( $\mathrm{F}$ tabel) dengan demikian Ho ditolak atau $\mathrm{H}_{6}$ diterima. Dengan demikian hal ini menunjukkan ada pengaruh yang signifikan antara variabel-variabel pertumbuhan penjualan (GS), struktur aktiva (FTA), profitabilitas (NPM), likuiditas (CR), ukuran perusahaan (SIZE) secara simultan terhadap struktur modal (DTA).

Model regresi berganda yang diperoleh dari hasil pengujian akan dijelaskan pengaruh variabel independen secara parsial (satu per satu) terhadap variabel dependen yaitu Debt to Total Assets (DTA).

\section{Pengaruh Pertumbuhan Penjualan (GS) Terhadap DTA}

Dari hasil perhitungan persamaan regresi linier berganda didapatkan nilai koefisien variabel GS sebesar $(-0,005)$. Hasil perhitungan uji secara parsial diperoleh nilai $t_{\text {hitung }}$ sebesar $(-0,093)$ dan nilai $t_{\text {tabel }}$ diperoleh 1,671 dengan nilai signifikansi sebesar 0,926 atau nilai signifikansi lebih besar dari $10 \%$. Ini menunjukkan bahwa variabel GS berpengaruh negatif secara tidak signifikan terhadap variabel struktur modal (DTA).

Sesuai kriteria uji t diperoleh hasil $(-1,671)<(-0,093)<1,671\left(-t_{\text {tabel }}<t_{\text {hitung }}\right.$ $\left.<t_{\text {tabel }}\right)$ sehingga dapat disimpulkan hipotesis antara variabel GS dengan variabel DTA tidak terbukti ada pengaruh positif secara signifikan $\left(\mathrm{H}_{1}\right.$ ditolak dan Ho diterima). Dengan demikian hasil penelitian ini tidak mendukung hipotesis meningkatnya pertumbuhan penjualan perusahaan yang dimiliki perusahaan, akan meningkatkan utang perusahaan.

Hal ini dimungkinkan terjadi pada perusahaan agribisnis, karena sektor agribisnis sangat erat kaitannya dengan kondisi alam. Misalnya saja PT. Bisi International Tbk (BISI), menghadapi kondisi yang disebabkan oleh pola cuaca yang terjadi selama periode tahun 2009 dan 2012, dimana pada tahun-tahun tersebut petani Indonesia dihadapkan dengan pola cuaca yang tidak biasa sehingga membawa pengaruh kurang baik bagi produksi tanaman komoditas. Dampaknya adalah penurunan permintaan akan produk perseroan dan tentunya terhadap kinerja perseroan secara keseluruhan.

Sementara pada struktur modal (DTA) PT. Bisi International Tbk melakukan ekspansi kapasitas produksi untuk mengantisipasi lonjakan permintaan produk tahun-tahun berikutnya. Selain hal tersebut, adanya kegiatan research and development khususnya pada pengembangan benih hibrida yang sudah menjadi keharusan perusahaan untuk meningkatkan daya saing 
produk walaupun dalam kondisi penjualan yang menurun bisa juga menjadi faktor pertumbuhan penjualan (GS) tidak berpengaruh positif secara signifikan terhadap struktur modal (DTA).

Hal tersebut diatas bisa juga diamati pada PT. Bakrie Sumatera Plantations Tbk (UNSP) yang berbasis pada usaha perkebunan komoditi sawit dan karet, terutama pada periode tahun 2009 dan 2012. Variabel struktur modal (DTA) UNSP meningkat dari periode sebelumnya sedangkan pertumbuhan penjualan (GS) mengalami penurunan bila dibandingkan dengan periode sebelumnya. Adanya penurunan GS periode tahun 2012 dikarenakan rendahnya permintaan pasar terkait krisis ekonomi yang melanda Eropa berimbas pada kecenderungan harga yang menurun pada komoditas sawit dan karet, serta rendahnya produktivitas kebun akibat pengaruh cuaca ekstrim dengan musim kering yang lebih panjang dan curah hujan yang sangat tinggi. Variabel struktur modal (DTA) yang meningkat terutama karena adanya kewajiban jangka panjang yang jatuh tempo.

Bagi PT. Wahana Phonix Tbk (WAPO), seiring dengan membaiknya kondisi perekonomian Indonesia pada tahun 2012 meningkatkan konsumsi masyarakat terutama pada barang konsumsi dan agroindustri yang memberikan pengaruh positif pada pertumbuhan penjualan (GS) perseroan yang bergerak dalam bidang perdagangan hasil pertanian dan kelautan, khususnya rumput laut (seaweed), beras, permen dan kedelai. Penataan kembali usaha perdagangan rumput laut (seaweed) dan pembelian aset pabrik permen pada tahun 2011 telah memberikan manfaat bagi perseroan dengan memberikan kontribusi penjualan yang signifikan. Untuk perbaikan pada struktur keuangan terutama pada variabel struktur modal (DTA), perseroan melakukan pembayaran, pelunasan kewajiban dan divestasi terhadap anak usaha yang memiliki kinerja kurang baik sehingga tidak lagi terbeban oleh biaya dan bunga yang tinggi.

\section{Pengaruh Struktur Aktiva (FTA) Terhadap DTA}

Dari hasil perhitungan persamaan regresi linier berganda didapatkan nilai koefisien variabel struktur aktiva (FTA) sebesar 0,799. Dari hasil perhitungan uji secara parsial diperoleh nilai $t_{\text {hitung }}$ sebesar 2,655 dan nilai $t_{\text {tabel }}$ 2,000 (a 5\%) dengan nilai signifikansi sebesar 0,010. Sesuai dengan kriteria uji t diperoleh hasil 2,655 $>$ 2,000 ( $t_{\text {hitung }}>t_{\text {tabel }}$ ) sehingga dapat disimpulkan hipotesis variabel struktur aktiva (FTA) berpengaruh positif secara signifikan terhadap struktur modal (DTA) terbukti ( $\mathrm{H}_{2}$ diterima dan Ho ditolak).

Berdasarkan pembahasan tersebut dapat disimpulkan bahwa hasil penelitian ini mendukung tinjauan pustaka dan hipotesa yang telah ditetapkan bahwa struktur aktiva (FTA) berpengaruh secara positif terhadap struktur modal (DTA). Secara statistik dapat dikatakan bahwa hubungan antara struktur aktiva (FTA) dengan strukur modal (DTA) adalah memiliki hubungan

Wahyu Handono, Effed Data, dan M. Zulkarnain Yuliarso. Analisa... | 234 
positif, yaitu jika terjadi kenaikan 1 unit struktur aktiva (FTA) maka akan mengakibatkan penambahan struktur modal (DTA) sebesar 0.799. Maka di dalam perusahaan agribisnis jika struktur aktiva (FTA) meningkat maka akan meningkatkan pula jumlah struktur modalnya (DTA), begitupun sebaliknya. Struktur modal (DTA) dalam hal ini mencerminkan utang perusahaan tersebut.

Perusahaan yang memiliki aktiva yang lebih besar, akan lebih mudah dalam memperoleh utang. Sehingga secara umum perusahaan yang memiliki jaminan terhadap utang akan lebih mudah mendapatkan utang daripada perusahaan yang tidak memiliki jaminan terhadap utang.

\section{Pengaruh Profitabilitas (NPM) Terhadap DTA}

Hasil yang diperoleh dari perhitungan persamaan regresi variabel profitabilitas (NPM) terhadap struktur modal (DTA) didapatkan nilai koefisien sebesar 0,030. Berdasarkan perhitungan uji variabel secara parsial diperoleh nilai $t_{\text {hitung sebesar } 0,363 \text { dan nilai } t}$ tabel 1,671 dengan nilai siginifikansi sebesar 0.718 atau nilai signifikansi lebih besar dari $10 \%$. Sesuai dengan kriteria uji $t$ maka diperoleh hasil $(-1,671)<0,363<1,671$ (- $\left.t_{\text {tabel }}<t_{\text {hitung }}<t_{\text {tabel }}\right)$ sehingga dapat disimpulkan hipotesis variabel profitabilitas (NPM) berpengaruh negatif secara signifikan terhadap struktur modal (DTA) tidak terbukti atau hipotesis ditolak ( $\mathrm{H}_{3}$ ditolak dan Ho diterima).

Hasil penelitian ini tidak mendukung teori bahwa perusahaan dengan tingkat pengembalian yang tinggi atas investasi menggunakan utang yang relatif kecil atau tingkat pengembalian yang tinggi memungkinkan untuk membiayai sebagian besar kebutuhan pendanaan dengan dana yang dihasilkan secara internal. Namun hasil penelitian ini mendukung teori Modigliani dan Miller yang telah membuat penjelasan tentang pajak bunga, perusahaan dengan tingkat keuntungan atau laba yang tinggi akan menggunakan utang yang besar untuk mendapatkan keuntungan dari pajak (Kartika, 2009). Selanjutnya penjualan saham baru justru merupakan sinyal negatif karena pasar menginterprestasikan perusahaan dalam keadaan kesulitan likuiditas. Penjualan saham baru tidak jarang mengakibatkan terjadinya delusi dan pemegang saham akan mempertanyakan kemana laba yang diperoleh selama ini (Kartika, 2009).

Hal ini bisa terjadi karena perusahaan dengan kondisi keuangan yang baik cenderung akan meminjam uang lebih sedikit, tetapi disisi lain tentunya akan menimbulkan ketertarikan investor ataupun kreditur dalam menanamkan modalnya atau memberikan utang. Ketika perusahaan berada dalam posisi laba, maka akan banyak investor ataupun kreditur yang ingin menanamkan modal atau memberikan utang pada perusahaan. Alasan lain hal ini bisa terjadi menurut teori Modligiani dan Miller disebabkan karena dalam keadaan pasar sempurna dan adanya pajak, pada umumnya bunga dibayarkan akibat penggunaan utang dapat digunakan untuk mengurangi penghasilan yang 
dikarenakan pajak atau dengan kata lain bersifat tax deductible. Dengan demikian, apabila 2 perusahaan yang memperoleh laba operasi yang sama tetapi yang satu menggunakan utang dan membayar bunga sedangkan perusahaan yang lain tidak, maka perusahaan yang membayar bunga akan membayar pajak penghasilan yang lebih kecil. Karena menghemat membayar pajak merupakan manfaat bagi pemilik perusahaan, maka nilai perusahaan yang menggunakan utang akan lebih besar dari nilai perusahaan yang tidak menggunakan utang (Kartika, 2009).

\section{Pengaruh Likuiditas (CR) Terhadap DTA}

Hasil perhitungan persamaan regresi linier berganda didapatkan nilai koefisien variabel likuiditas (CR) sebesar $(-0,026)$. Dari perhitungan uji secara parsial diperoleh nilai $t_{\text {hitung }}$ sebesar $(-5,206)$ dan nilai $t_{\text {tabel }} 2,660$ (a 1\%) dengan nilai signifikansi sebesar 0,000. Sesuai dengan kriteria uji t maka diperoleh hasil $(-5,206)<(-2,660)\left(-t_{\text {hitung }}<-t_{\text {tabel }}\right)$ sehingga dapat disimpulkan hipotesis variabel likuiditas (CR) berpengaruh negatif secara signifikan terhadap variabel struktur modal (DTA) terbukti ( $\mathrm{H}_{4}$ diterima dan Ho ditolak).

Hal ini mengindikasikan bahwa semakin besar likuiditas perusahaan akan berpengaruh negatif terhadap struktur modal (DTA) yang mencerminkan utang perusahaan. Semakin tinggi kemampuan perusahaan dalam melunasi kewajiban-kewajiban jangka pendeknya maka hal tersebut dapat mengindikasikan perusahaan berada dalam keadaan yang sehat. Hal ini sesuai dengan pecking order theory, perusahaan yang mempunyai likuiditas yang tinggi akan cenderung tidak menggunakan pembiayaan dari utang. Hal tersebut dikarenakan kecilnya resiko yang ditanggung perusahaan apabila menggunakan pendanaan internal.

\section{Pengaruh Ukuran Perusahaan (Size) Terhadap DTA}

Hasil yang diperoleh dari pengujian regresi nilai koefisien variabel ukuran perusahaan (Size) didapatkan sebesar $(-4,058)$. Dari perhitungan uji secara parsial diperoleh nilai $t_{\text {hitung }}$ sebesar $(-1,886)$ dan nilai $t_{\text {tabel }} 1,671$ (a 10\%) dengan nilai P-value atau tingkat siginifikan sebesar 0.064. Berdasarkan nilai signifikansi, P-value dinyatakan signifikan karena nilai signifikansi lebih kecil dari $10 \%$. Berdasarkan kriteria hipotesis uji t maka diperoleh hasil $(-1,886)<(-$ $1,671)$ atau (- $\left.t_{\text {hitung }}<-t_{\text {tabel }}\right)$ sehingga dapat disimpulkan hipotesis variabel Size berpengaruh negatif secara signifikan terhadap struktur modal (DTA) terbukti ( $\mathrm{H}_{5}$ diterima dan Ho diterima).

Maka dapat disimpulkan dalam perusahaan agribisnis jika ukuran perusahaan (Size) meningkat maka akan menurunkan jumlah struktur modal (DTA). Hal ini bisa terjadi akibat adanya resiko perusahaan yang tumbuh dengan pesat sering menghadapi ketidakpastian yang lebih besar, sehingga perusahaan cenderung mengurangi keinginan untuk menggunakan utang. 
Terlebih lagi pada perusahaan agribisnis, resiko ketidakpastian perusahaan juga dapat dipengaruhi oleh faktor alam. Selain itu investor dapat memperoleh lebih banyak informasi dari perusahaan besar jika dibandingkan dengan perusahaan kecil. Jadi, dengan diperolehnya dana lewat pasar modal menjadikan proporsi utang menjadi semakin kecil dalam struktur modalnya.

\section{SIMPULAN DAN SARAN}

\section{Simpulan}

Berdasarkan hasil analisis, penelitian ini menyimpulkan bahwa:

1. Variabel pertumbuhan penjualan (GS) berpengaruh negatif terhadap variabel struktur modal (DTA). Artinya pada perusahaan agribisnis pertumbuhan penjualan tidak terbukti akan meningkatkan struktur modalnya.

2. Variabel struktur aktiva (FTA) berpengaruh positif secara signifikan terhadap variabel struktur modal (DTA). Artinya meningkatnya struktur aktiva perusahaan agribisnis akan meningkatkan struktur modalnya.

3. Variabel profitabilitas (NPM) berpengaruh positif terhadap variabel struktur modal (DTA). Artinya meningkatnya profitabilitas pada perusahaan agribisnis tidak terbukti akan menurunkan struktur modalnya.

4. Variabel likuiditas (CR) berpengaruh negatif secara signifikan terhadap variabel struktur modal (DTA). Artinya meningkatnya likuiditas pada perusahaan agribisnis akan menurunkan struktur modalnya.

5. Variabel ukuran perusahaan (Size) berpengaruh negatif secara signifikan terhadap variabel struktur modal (DTA). Artinya meningkatnya ukuran perusahaan agribisnis akan menurunkan struktur modalnya.

6. Bahwa variabel pertumbuhan penjualan (GS), struktur aktiva (FTA), profitabilitas (NPM), likuiditas (CR) dan ukuran perusahaan (Size) secara bersama-sama (simultan) berpengaruh secara signifikan terhadap variabel struktur modal (DTA) perusahaan agribisnis.

\section{Saran}

Saran-saran yang dapat diberikan melalui hasil penelitian ini baik kepada investor, perusahaan maupun pengembangan penelitian lebih lanjut adalah sebagai berikut:

1. Investor perlu memperhatikan dan mempertimbangkan komposisi rasio struktur aktiva, likuiditas dan ukuran perusahaan dalam menilai struktur modal perusahaan agribisnis. 
2. Investor jangan terlalu khawatir dengan fluktuasi pertumbuhan penjualan (GS) perusahaan agribisnis karena terkadang kendala yang dihadapi perusahaan karena disebabkan oleh faktor cuaca.

3. Penelitian ini hanya terbatas pada kajian empiris tentang faktor - faktor yang mempengaruhi struktur modal perusahaan agribisnis di Bursa Efek Indonesia tetapi tidak sampai kepada dampak struktur modal itu sendiri terhadap kinerja perusahaan. Oleh karena itu, peneliti lain yang berminat terhadap permasalahan struktur modal perusahaan agribisnis dapat mengembangkan penelitian ini dalam rangka mengetahui dampak dari struktur modal yang digunakan perusahaan terhadap kinerja perusahaan agribisnis.

4. Berdasarkan $\mathrm{R}$ square, persentase variabel independent mempengaruhi varibel dependen baru sekitar $41 \%$, artinya peneliti selanjutnya dapat menambahkan lagi variabel-variabel lain yang belum diamati dalam penelitian ini.

5. Peneliti selanjutnya dapat menambah periode waktu pengamatan dalam riset menjadi lebih panjang, misalnya 10 tahun atau mengubah periode waktu pengamatan. Periode yang panjang diharapkan dapat menangkap pola perilaku variabel yang mempengaruhi struktur modal menjadi lebih tegas dalam tingkat signifikansi pengungkapan tandanya.

6. Penelitian ini dilakukan dengan menggunakan data tahun 2007 - 2012, sehingga untuk tahun - tahun yang lain atau tahun - tahun mendatang hasil penelitian ini masih perlu diuji kembali.

\section{DAFTAR PUSTAKA}

Harmono, 2009. Manajemen Keuangan; Berbasis Balanced Scorecard Pendekatan Teori, Kasus dan Riset Bisnis. Bumi Aksara. Jakarta.

Indonesian Capital Market Directory (ICMD). Periode 2007 - 2012. Bursa Efek Indonesia. Jakarta.

Kartika, Andi. 2009. Faktor-Faktor Yang Mempengaruhi Struktur Modal Pada Perusahaan Manufaktur Yang Go Public Di BEI. Jurnal Dinamika Keuangan dan Perbankan. Vol 1 No 2.

Kuncoro, Mudrajad. 2003. Metode Riset Untuk Bisnis \& Ekonomi. Erlangga. Jakarta.

Wijayati Patri dan Janie A Dyah. 2012. Faktor-Faktor Yang Mempengaruhi Struktur Modal Pada Perusahaan Manufaktur Yang Go Public Di Bursa Efek Indonesia Periode 2005-2010. Juraksi. Vol 1 No 1.

Wahyu Handono, Effed Data, dan M. Zulkarnain Yuliarso. Analisa... | 238 